\title{
Teaching and Learning Interactional Patterns in Speaking Subject at Several Higher Educational Institutions
}

\author{
Ngatmini \\ PGRI University of Semarang, Indonesia
}

\begin{abstract}
This study seeks to find the models applied in interactional pattern of teaching and learning activities on speaking subject in both religious and non-religious universities. In this qualitative study, a realistic ethnographic approach was used. The researchers played a key role as the research instrument. The data are lecturers and students' speech fragments in learning and teaching speaking skills. The instruments were technically obtained through observation using video recording. The data sources are the lecturers and students' spoken transcripts. The result of this study proved that teaching and learning interactional patterns on speaking subject at the religious based universities revealed that they are under the lecturers' control. In religious universities, the lecturers speak more than students (TTT), whereas in non-religious universities students are given more speaking opportunities (STT). Interaction occurs when students construct their experience and knowledge with the received information. Lecturers at both universities were not able to facilitate students developing and expressing their ideas. Both religious and non-religious universities' learning and teaching interactional patterns at the speaking subjects implemented towards constructivism. Through generative learning strategy, some elements reflect each step of the strategies, although at an early stage. It is necessary to develop varied learning models which engage students' active participation. In addition, there should be an understanding towards the concept of classroom interactional competence.
\end{abstract}

Index Terms - interactional patterns of learning and teaching, speaking, classroom discourse

\section{INTRODUCTION}

The essence of learning concerns with a process of interaction between educators and learners. In a learning situation,the learners are given their access to the educators' facilities in order that they can experience efectively the learning process. Bearing in mind, the key learning process is on the interaction between participants, educators and learners, and learning in collaboration (Sue et al., 2005). Allwrigh and Ellis (1991) argue that successful learning is closely related to the success of interactional management. The most influential factor in students' development and coaching is the educators (Kauchak, 2012). Banner and Todd (cited in Frances, 2002) suggest that the way an educator speaks shows the impact on students' learning.

In an interaction of both teaching and learning activities, speaking skills mastery is quite significant. Since speaking is a second language learning method people do as a kind of linguistic acquisition after having leared from listening. Speaking ability can be an effective measurement to understand a language (Bashir et al, 2011). Speaking skill is a typical skill in producing spoken language containing messages to convey others (Nurgiyantoro, 2012; Ahmadi, 1990).Speaking activity according to Florez (cited in Ismail, et al, 2011) is an interactive process in constructing certain meanings that involve the production, acceptance and processing of information. A speaking skill is about spontaneous, open-ended and naturality. Such skills are of pivotal requirement to build information acquired fromthe existing selfexperience or knowledge. In fact, the speaking skills embodiment remains difficult and confronts with a lot of constrains to realize the ideal teaching-learning interaction. This situation may not only occur to Indonesian students. An evidence from Thai as Punthumasen noted that (Buenner, 2013) the Thai learners have low English speaking skills, while in the dominant lecture / explanatory lesson, learners were asked to write down the lesson from the board and memorize them. This situation according to Saengboon and Wongsothorn, et. al. (Buenner, 2013) that English learning in Thailand has too much content in the curriculum, educators, burdens and excessive responsibility, in addition to there are abundant students within a class.

In Indonesian context, Untoro's research (2010) indicated thatthe Indonesian learners speaking abilityis belowaverage, the significant difference lays on the educators' dominant roles within the learning process, consequently learners are not given much opportunity to train their speaking abilities. Similarly, the observations made in classroom activities, the lecturers who control the learning. As noted by Edwards and Wastgate (1994). that in a formal education, the learning as a 'verbal meeting' is arranged by lecturers, the learning takes place in one direction, in such a case, the lecturers takemore dominantroles in teaching and learning process.

The teacher's role in shaping class interaction needs to be reconsidered, as is the idea of teaching the whole class. The lecturers may not just to organize the exercises. Indeed, in most parts of the world, if they just "handed in" to students, 
lecturers will be criticized for not doing their job or be accused of neglecting responsibility. The lecturer's assumption of being a 'mere facilitator' may be a middle-class, western, and culture-bound perspective (Walsh, 2006). In line with this fact, evidence from the field shows that learning pattern is still dominated by educators, Untoro's (2010) results emphasize the classroom conversation, dominant lecturer's role, consequently leads into the ineffectiveness of students'slearning speaking competence since they are not given subsequent opportunity to speak by their own. Similarly, further argued by Liu and Thao (2012) that lecturers' speaking time allocation surpass the students'. The dominant IRF pattern (Initiation Feedback) often time prevails in classroom. The discussed issues in this study centered on how the interactional patterns of teaching and learning speaking courses at thereligious and non-religious universities?

Although feedback is called educators as implications (Allright, Bailey, 1991) other researchers instead propose a variable approach to feedback in interactional discourse. Kasper (1986), i.e., explains that specific implication strategies are either preferred or dispreferred based on the lecturers' objectives, as opposed to 'centralized language' with 'central content' improvements. Van Lier (1988) concludes that improvement is "closely related to the context of what is being done", the implication being that improvement, like other aspects of classroom discourse, is farily good, or should be, related to pedagogic purposes.

Kasper (2001) argues that the IRF sequence often negatively considered in the language classroom, bearing in mind the learners are only traditionally given minimum interactional space. He goes on to suggest how this position is enhanced when teachers offer learners greater participation in addition to involve more central position in interaction. McCarthy (2003) further explains that 'listeners' on IRF exchanges: students' ability to recognize their involvement in discourse even in an interaction despite the fact that they are not the main speakers. Obviously, as McCarthy underlined, such typical language skill closely related to speaking instead of listening. Arguably, this is a skill that teachers can encourage through more careful interaction with learners (Walsh, 2006).

Studies on classroom discourse undertaken by previous researchers among others Smith (1976), Chadia (2011), Husna, et al (2015), Andryani (2011), Kumpul (2012), Xhemaji (2016). The analyses were typically applied to the research subjects ranging from early childhood up to students of various educational levels by using corpus analysis, conversation linguistic, FIACS. However, previous research results limited on both presenting data analysis and measuring the teachers and learners' participation, none of the researchers concern examining the interactional pattern of teaching and learning in universities. In this article, I analyze the conversations took place between lecturers and students in college.

Discourse analysis according to Brown and Yule (1995) "is the analysis of language in use". This restriction is based on functional language, which means discourse analysis examines what language is used. McCarthy (2003) further points out that discourse analysis deals with the study on the relationship between language and context in a language usage. Thakur (Amatari, 2015) defines a class interaction analysis as "an instrument designed to record verbal interaction categories during, or from, recording teaching and learning session. This is a technique to capture qualitative and quantitative dimensions of the teacher's verbal behavioral activities within the classrooms."The analysis is an analysis of discourse in the classroom and behind the classroom'. Class is the main context of the discourse object of study. 'Context' for discourse analysis underlies communication in both within and beyond the classes. Classroom conversation at the beginning will be different from the final conversation. It describes the classroom teaching and learning interactional patterns. Many contexts influencing what things are spoken and interpreted. Everything spoken in a classroom affects the context underlying it.

Learning and teaching interactional patterns is based on personal point of view. In this study, the teaching and learning interactional pattern is conducted especially to cope with problems on the educators and learners' activities, basic learning interactional pattern, in accordance with constructivism through generative learning strategy (Sardjiyo \& Pannen, 2005). Teaching and learning interactional patterns in speaking subjects commonly consist of constructed activities from beginning, core, and to the end. In addition to the strategy use is generative learning strategy consisting of four components, namely motivational component, learning process, process of creation and process generation. The general activities pattern consists of the initial, core, and closing activities. The strategy used is generative learning strategy.

\section{METHODS}

This study was designed with qualitative methodology (Moleong, 1995), (Sugiyono, 2010) and is based on realistic ethnographical approach (Creswell, 2015).Researchers are cosidered the 'objective' observers sincethey are observing the record facts, interactional events in classrooms objectively. The research design adopted classroom discourse analysis. The data are obtained from lecturers and students' speaking fragments on the learning and teaching activities of speaking skills at religious and non-religious universities. The instrument of analysis uses observation on recorded videos which arethen transcribed. The data sources are lecturers and students' at religious universities such as the Sultan Agung University of Semarang and Muhammadiyah University of Surakarta, while the non-religious universities are the Surakarta State University (UNS) and PGRI University of Semarang. Data analysis implemented Miles and Huberman's interactive model (Creswell, 2015), conducted in four stages, namely data collection, data reduction, data presentation, and the conclusion or verification of the findings. 


\section{RESULTS AND DISCUSSION}

The teaching and learning interactional pattern of speaking subjects in religious and non-religious universities has led to constructivism which is dominantly controlled by lecturers although the quality of constructivism may be different.The levels of lecturers' control over students in religious universities is higher than that of non-religious universities. However, in religious universities, religious values contributing to character inculcation is higher than the non-religious universities.

The occurring interactional patterns are divided into early activities, the core that includes motivating activities, learning process, creation process, and generation process. The construction established by students have not yet emerged and evolved out of the knowledge understanding or students' personal experiences. Students usually come out with ideas because they are assigned by the lecturers, related telling stories, taking a role as master of ceremony or host, speech delivery, discussion practice, or debate. Therefore, the students' performance has not shown optimal results. This is illustrated by the number of lecturers' inputs to the students for the mistakes made.

Learning in religious colleges is strongly affected by religious values. In Unissula, the Qur'anic values transmission is presented to students as obligatory thing to do by the lecturer(s) in each lecturing time. Even the lecturers ought to follow several stage training programs before carrying out academic tasks. Learning device product as proof of readiness of lecturers to carry out learning in class.In RPS, the lecturers were also incorporating the initial activities of learning in which the letter and verse are written in relation to the lecturing materials. In UMS, students normally perform prayers at the beginning of lecturing time which has been entrenched. However, in non-religious universities, students inclined towards experiencing the learning process. The interactional pattern of teaching and learning subjects in religious and non-religious universities presented in the following table.

TABLE 1.

TEACHING-LEARNING INTERACTIONAL PATTERN OF SPEAKING SUBJECTS IN RELIGIOUS AND NON-RELIGIOUS UNIVERSITIES

\begin{tabular}{ccccc}
\hline Universities & UNISSULA & UMS & UPGRIS & UNS \\
\hline Activities & $\begin{array}{c}\text { Engage } \\
\text { Initial Processes }\end{array}$ & $\begin{array}{c}\text { Engage } \\
\text { lecturer-student }\end{array}$ & $\begin{array}{c}\text { Engage } \\
\text { lecturer-student }\end{array}$ & $\begin{array}{c}\text { Engage } \\
\text { lecturer-student }\end{array}$ \\
\hline $\begin{array}{c}\text { The Core of } \\
\text { Learning process }\end{array}$ & $\begin{array}{c}\text { Study } \\
\text { lecturer-student }\end{array}$ & $\begin{array}{c}\text { Active } \\
\text { student-lecturer-student }\end{array}$ & $\begin{array}{c}\text { Study } \\
\text { lecturer -student }\end{array}$ & $\begin{array}{c}\text { Active } \\
\text { student-student }\end{array}$ \\
\hline $\begin{array}{c}\text { The Process of } \\
\text { Creation }\end{array}$ & $\begin{array}{c}\text { Active } \\
\text { student-lecturer }\end{array}$ & lecturer-student & Active & Active \\
Generation & Engage & student-student & student-student \\
\hline lecturer-student & student & Active & sctive \\
student & student-student \\
\hline lecturer-student & Study & Study & Study \\
Average Values & lecturer -student & lecturer-student & Lecturer-lecturer \\
\hline
\end{tabular}

Harmer (Prilanita, and Sukirno, 2017) argues that ESA (Engage Study Activate) as a strategical embodiment of an effective learning atmosphere. In table 1, it is presented the learning between lecturers and students, there are four universities as the research samples, they are the Unissula, UMS, UPGRIS, and UNS. ESA may occurs at various learning, in Unissula there occured ESAES, in UMS there was occured EASAS, while in UPGRIS occured ESAAS, and similarly in UNS the EAAAS was occured.

In Unissula, the learning is described with ESAES, which means students are involved in question and answer (Q\&A) learning towards the level of knowledge followed by informational provisions by the lecturers. Students are given the opportunity to practice their speaking skills within a discussion session is controlled by the lecturers. In this case, the students are re-enrolled in interactive lecture learning, one who guides the learning is the lecturer. At the end, the lecturer provides a discussion as a practical realizationin lectures form accompanied with Q\&A sessions. In contrast to UMS, speaking lessons are described with EASAS. The learning begins with Q\&A on some materials to be discussed, practically, studentsare involved in this learning processand is controlled by the lecturer. The learning followed by students' speaking practice of telling stories in front of the classroom individually along with setting up a discussion by both lecturers and students. At the discussion session, the lecturer further elaborated the related theory. The practical learningof speaking subjects at UMS were developed in vary. There is the learning materials in Q\&A modul classified into inter-grouping students. The classes are divided into two groups, namely the questioner group and the answering group. The purpose of such a learning model is to encourage students' active roles.At the Q\&A session, lecturers often time found either give their commentswith affirmations or appreciationfor the good answers. However, the lecturers pay less attention to students asking question activity. Since all students have to set up questions and answers, then there were found some students asking for questions opening the module, in addition to students who answeringthe questions and searching for the answers according to the module.

Learning activities at UPGRIS and UNS show more students active role because the learnings are in presentation and debate forms. In both of these universities, speaking learning begins with information from lecturers who engaged the students' active roles. The students' next activities is the presentation and debate. In theUPGRIS students' presentation 
activity,significant interactive interaction tends to be occured. The response is realized in referential question form, which was primarily addressed to the presenters. This consequently leads the presenters into having critical thinking to answeringfor questions. The questions are: Lah, apakah ada solusi dari Mbak Novita supaya saya tidak panik?" [Trans. Is there any sollution from Miss Novita to avoid being panic].At the presentation session, students delivering questions using the guidance or introductory before the question was asked, the students who were being asked can be explainedin complex. This is asillustrated by Berns (Prilanita, and Sukirno, 2017) ", Experience with peers enable children to acquire a wide range of skills, attitude, and roles that influence their adaptation throughout life". Students who are interacting with fellow students as peers, their various skills, attitudes, and roles influenceing the adaptation in communication. This opinion is also relevant to what has been elaborated by Chadia (2011), that students who were being asked withan open question, their answers remain longer and quite complex.

The expressed opinions are in a along and complex form of sentences additionally occur in speaking learning at UNS. Themethod use in UNS aplied the debate model. The debates were directed by the students.In the debate, there are pro teams, counter teams, supporters of the pro teams, supporting group of the counter team, and jury teams, however, in this case, the lecturers take a role as observers. The prevailing interactional circumstancesin both universities remain different, in UPGRIS the proposed opinions are still limited to the discussed topics, whereas in UNS the typical long argumentation presented,areoften time found less relevant to the arguments presented by the opposing team, due tothe opposing teams' lack of understanding over the discussed materials.

Teaching and learning interactional patterns in both religious and non-religious universities, it is found they are applying typical learning steps toward constructivism, but early constructivism. This is evidenced in the activities of generative learning steps strategy are found, even though only few found, such as learning process steps are in the activities of students who provide responses, as marked by B6.

Lecturer : :Kemudian saya ingin memberikan bahasa non verbal yang alatnya adalah tubuh kita sendiri, kalau saudara menyatakan setuju dengan bahasa tubuh kita". [Trans. And, I would be giving you non verbal language, by which our body is the only means, if only you are in agreement with our body language]

Students : [nodding].

In the process of creation, students came up with their thoughts and ideasas was shown from C and D 5-6. ?"as explained at below fragment A6.

Lecturer : "Ada yang punya trik lain nggak? Ini nanti kan kita baca ke bawah. Tapi ada yang punya trik lain bagaimana cara mengatasi grogi?” [Trans. Anybody has another trick?, this what we shall read downward. But, is there anybody has another trick to overcome getting nervous?]

Students:: : “Ada pak!" [Yes sir!, we got one]

In undergoing learning-teaching interactions at religious universities, the lecturers frequently took more dominant role. The typical model applied by lecturers in learning is lecturing in addition to provide for questions and answers time. Learning processes which took place in such university shows the lecturers' active roles than students. This is in line with Harmer's suggestion (Harmer, 2001)., that a good educator is an educator who maximizes the students'sactive roles or Student Talking Time (STT) conversely educators who dominantly take over the classroom's conversation is the so called Teacher Talking Time (TTT). However, these two universities share similar significant advantages to be compared to the non-religious universities, where in such universities students are mostly taught about noble characters inculcation. Among the inculcated noble characters are praying, connecting everything learned under the God's Suprime Power. Even in Unissula, teaching preparation (RPS) should include the learning resources which in line with Qur'anic values.

In the non-religious universities, students are given the opportunity to actively perform the learning process. Although the students have not been able to construct the knowledge gained with the knowledge or experience they have. The information conveyed in the learning is, therefore, still limited by certain topics. There is the needs for being facilitated by the lecturers, thus the interactions develop optimally as part of their critical thinking. As referred to Shahi (Husna, 2015). Flanders similarly assumes that the educators share influential authority in the classroom, because lecturer's talk and things being delivered were primarily determined by the students' great reactions.

This may also affect he students' academic achievement. In line with Good and Brophy's opinion (Kauchak, 2012) that the lecturers' verbal behavior in classroom affects students' academic achievement. The above table shows the average value achieved by students. Religious universities among others the Unissula with the average of 73; UMS 69, while non-religious universities are the UPGRIS 79.8 and UNS 83.5. These values illustrated that the religious universities are lower than that the non-religious universities. In religious universities, ranging from the C / B category and non-religious universities are in B category. In religious universities, the interactional pattern is dominantly controlled by lecturers, while in non-religious universities, students' interaction is fairly good, the achievement value is in B category. The achievement value is relevant to Bailey's opinion (cited Ismail, et al, 2011). that speaking skill is more difficult than other skills.

\section{RESULTS AND DISCUSSION}

The results of this research conclude that both teaching and learning interactional pattern of speaking subjects at the 
religious universities is mostly controlled by the lecturers. In religious universities lecturers speak more than students (TTT) whereas in non-religious universities both lecturers and students are given a lot of opportunities to speak (STT).It affects student achievement. Both groups of universities have not been able to achieve an A because students have not been able to optimally interact. An interaction occurs at the time students constructing their experience and knowledge with the received information. Lecturers at both universities have not been able to facilitate students with selfdevelopment and ideas expressions, both religious and non-religious universities interactional patterns of the learning and teaching speaking subjects towards constructivism. Through generative learning strategy in learning, there were found elements reflecting each step of the strategies, despite at the early stage. It is necessary to develop varied learning models that involve learners' participation. In addition, there should be an understanding of the concept of classroom interactional competence.

The results of this study may significantly contribute the educators' insight into the importance of teaching-learning interaction between educators and learners. The creation of interactional learning is perceived to be a successful achievement of students' learning objectives. In addition, the results of this study can be used as a rationale that all educators determine the learners'learning achievements, such as motivation, the delivery of questions, and the selected learning models.

\section{REFERENCES}

[1] Ahmadi, Mukhsin.(1990). Strategi Belajar Mengajar Keterampilan Berbahasa dan Apresiasi Sastra. Malang: YA 3 Malang.

[2] Allwright, R.L. and Bailey, K. (1991) Focus on the Language Classroom: An Introduction to Classroom Research for Language Teachers, Cambridge: Cambridge University Press

[3] Amatari, Veronica odiri. (2015). "The Instructional Process: A Review of Flanders' Interaction Analysis in a Classroom Setting". International Journal of Secondary Education, 3, (5), October 2015, pp. 43-49, retrieved from: http://article.sciencepublishinggroup.com/html/10.11648.j.ijsedu.20150305.11.html\#.

[4] Andriany, Liesna. (2011). "Ujaran Interpersonal dalam Wacana Kelas (Analisis Linguistik Sistemik Fungsional)".[Desertasi].Sekolah Pascasarjana Universitas Sumatera Utara Medan

[5] Bashir, M., Azeem, M., \& Dogar, A.H. (2011). Factor Effecting Students' English Speaking Skills., British Journal of Arts and Social Sciences, 2 (1), 2011,retrieved from: http://www.bjournal.co.uk/BJASS.asps, on July $21^{\text {st }} 2019$.

[6] Brown, G., \& Yule, G. (1999). Teaching the Spoken Language. Cambridge: Cambridge University. Press, pp.143-148

[7] Buenner, Patcharee - Scheb. (2013). "Do Scaffolding Interactions Exist in the Thai Classroom?" GEMA Online® Journal of Language Studies, 13, (3),September 2013, pp.17-30, retrieved from: http://journalarticle.ukm.my/6591/, on July 24 th 2019.

[8] Chadia, Chioukh. (2011). "Interaction in teachers/learners and learners/learners' Discourse : the case of third year oral expression students/teachers at Mohamed Saddik Ben Yahia University-Jijel”.[Desertation]. Faculty of letters and language department of English, University of Ferhat Abbas-Setif.

[9] Creswell, J.W., (2015, 4th Eds). Research Design : Qualitative, Quantitative and Mixed. Methods Approaches. Sage publications, Inc.

[10] Edwards, D., \& Westgate, D. (1994). Investigating Classroom Talk. London The Falmer Press, pp. 83-97.

[11] Frances, Christie. (2002). Classroom Discourse Analysis: A Functional Perspective. Printed and bound in Great Britain by MPG, Bodmin, Cornwall. London \& New York:Continuum, pp. 166-168

[12] Hai, See Kin and Lim Siew Bee. (2006). "Efectiveness of Interaction Analysis on the verbal Behaviour of Primary School Mathematics Teacher". Jurnal Pendidik dan Pendidikan, 21, 115-128

[13] Harmer, Jeremy. (2001). How to Teach English: Anintroduction tothe Practiceof English Language T eaching. Malaysia:VVP.

[14] Husna, Arina Hafadhotul,Rudi Hartono, Ahmad Sofwan. (2015). "Teacher's And Students' Talks And Their Nonverbal Communication In The Classroom Interaction”. English Education Journa, EEJ, 5 (1), (2015), pp. 121-132, retrieved from: http://journal.unnes.ac.id/sju/index.php/eej, on July 19th 2019.

[15] Ismail, Zawawi, Ab Halim Tamuri, Nik Mohd Rohimi Nik Yusoff, Mohd Ala-Uddin Othman. (2011). Teknik Pengajaran Kemahiran Bertutur Bahasa Arab Di SMKA Di Malaysia. GEMA Online ${ }^{\mathrm{TM}}$ Journal of Language Studies 67, (11), 2 May 2011.

[16] Kasper, G. (1986). 'Repair in foreign language teaching', in G. Kasper (ed.) Learning, Teaching and Communication in the Language Classroom, Aarhus: Aarhus University Press, pp. 54-59

[17] Kasper, G. (2001). 'Four perspectives on L2 pragmatic development', Applied Linguistics, 22: 502-30.

[18] Kauchak, Paull Eggen Don.(2012). Strategi dan Model Pembelajaran. Jakarta: PT.Indeks.

[19] Kumpul, I Nengah. (2012). "Classroom Interaction Analysis" in Bilingual Science Classes In SMAN 4 Denpasar. Language Education of Postgraduate Program, Ganesha University of Education Jl. Udayana, Singaraja

[20] Liu, Jingxia and Thao Le. (2012). "A Case Study on College English Classroom Discourse", International Journal of Innovative Interdisciplinary Research, 1 April, 2015,

[21] McCarthy, M.J. (2003). 'Talking back: "small” interactional response tokens in everyday conversation', Research on Language in Social Interaction, (1), 36, pp. 33-63, retrieved from: http://www.cs.cmu.edu/ dgroup/papers/mccarthy2003.pdf.

[22] Miles, Mathew B. dan A. Michael Huberman. (1988). Analisis Data Kualitatif. Terjemahan Tjejep Rohendi Rohidi.Jakarta: Universitas Indonesia.

[23] Moleong, Lexy J. (1995). Metodologi Penelitian Kualitatif. Bandung: Remaja Rosda Karya.

[24] Nurgiyantoro, Burhan. (2012). Penilaian Pembelajaran Berbahasa Berbasis Kompetensi. Yogyakarta: BPFE.

[25] Prilanita, Yeni Nur dan Sukirno. (2017). "Peningkatan Keterampilan Bertanya SiswaMelalui Faktor Pembentuknya". Cakrawala Pendidikan, (2), Juni, 2017.

[26] Sardjiyo \& Pannen, P. (2005). "Pembelajaran Berbasis Budaya: Model Inovasi Pembelajaran dan Impelentasi Kurikulum berbasis Kompetensi". Jurnal Pendidikan, 6, (2), pp. 83-98. 
[27] Smith, Eldon Cale. (1976). “A Latitudinal Study of Preservice Instruction in Flanders' Interaction Analysis Categories".Dissertation.Arizona State University.Spons Agencyoffice of Education (DHEW), Washington, D.C.

[28] Su, Bude, Curtis J. Bonk, Richard J. Magjuka, Xiaojing Liu, dan Seung-hee Lee. (2005). "The Importance of Interaction in Web-Based Education:A Program-level Case Study of Online MBA Courses". Indiana University. Journal of Interactive Online Learning, 4, (1), Summer 2005, retrieved from:https://www.google.co.id/journalteachingandlearninginteractions, on July 17 th 2019.

[29] Sugiyono. (2010). Metode Penelitian Pendidikan Pendekatan Kuantitatif, kualitatif, dan R\&D. Bandung: Alfabeta

[30] Untoro, Raharjo Dwi. (2011). “Analisis Wacana Lisan Interaksi Guru Dan Siswa Di Kelas (Studi Kasus Pemakaian Bahasa Di Sma Negeri 3 Sragen dalam Mata Pelajaran Bahasa, retrieved from: https://digilib.uns.ac.id/dokumen/detail/14037/Analisiswacana-lisan-interaksi-guru-dan-siswa-di-kelas-studi-kasus-pemakaian-bahasa-di-SMA-Negeri-3-Sragen-dalam-matapelajaran-Bahasa-Indonesia-Biologi-dan-Sosiologi on July 23rd 2019, Thursday at 05.45 AM.

[31] van Lier, L. (1988a). The Classroom and the Language Learner, London: Longman, pp. 28-36

[32] Walsh, Steve. (2006). Investigating Classroom Discourse. New York: Routledge, pp 161

[33] Xhemajli, Arbona. (2016). "Impact of Interactive Teaching on the Efficient Realization of Objectives for Children in Early School Age". Tirana-Albania: Academic Journal of Business, Administration, Law and Social Sciences, 2 (1), 2016, pp. 86-93, retrieved from: www.iipccl.org IIPCCL Publishing.

Ngatmini, is a lecturer and doctor at the faculty of teacher training and education, in Indonesian Language Education and Letters Major Study, PGRI University of Semarang, Central Java, Semarang, Indonesia. 